og hos Lacan (Lilian Munk Rösig), den bevæger sig dernæst over til den tidlige poststrukturalisme hos Derrida (Adam Diderichsen), Foucault (Sverre Raffnsøe \& Marius Gudmand-Høyer) og Laclau (Allan Dreyer Hansen) og afsluttes med de 'vilde' poststrukturalister, Zizek (Carsten Bagge Laustsen), Deleuze \& Guattari (Martin Fuglsang, Michael Pedersen \& Bent Meier Sørensen) og endelig med Luhmann (Anders Esmark).

Undertegnede fandt størst fornøjelse $i$ at læse om poststrukturalisterne men til gengreld mest udbytte - da det var mindre velkendt - af at læse om socialkonstruktivismen. Meget mere kunne have været inddraget, men da det altid er tilfældet skal redaktørerne ikke klandres for deres valg. Begge bøger indledes med en artikel af redaktørerne omkring hhv. socialkonstruktivisme og poststrukturalisme (der bærer præg af at være skrevet i sidste øjeblik, da de er fyldt med fejl), der sætter dem i forhold til hinanden som to selvstændige traditioner, der forklarer deres historie( $(\mathrm{r})$, og som markerer deres status som netop analysestrategier. Velfodret med det teoretiske venter vi nu på to bind med socialkonstruktivistisk og poststrukturalistiske analyser. Mikkel Thorup

\section{Da mennesket blev menneske - og fik en historie}

Peter K. A. Jensen: Da mennesket blev menneske, Gyldendal, 2004, 334 sider, kr. 349,- og Peter K. A. Jensen: Menneskets oprindelse og udvikling, Gyldendal, 2005, 432 sider, kr. 449,-

Det er ganske klassisk at sondre mellem forhistorisk og historisk tid ved hjxlp af skriften. Det afgørende snit for historisk tid må derfor henføres til udviklingen af kileskriften $i$ den sumeriske civilisation, 3000 år f.v.t.. Selv om der er en god grund til at gøre dette snit, idet der med skriften opstår en teknik der tillader os, at fastfryse begivenheder og opnå en hukommelse ned gennem tiden, så har det desværre forledt til den misforståelse, at historie er noget der er forbeholdt de sidste 5000 år. Det er det ikke. Menneskets historie udgøres af mindst 6 millioner år, og den klode vi er så afhængige af for udfoldelsen af vort korte liv, har en endnu længere historie. Det er derfor vigtigt for forståelsen af menneskets udvikling $\mathrm{i}$ 'historisk tid', hvorledes vi overhovedet kom til denne 'tid'.

Videnskaben om menneskets udvikling $i$ dette tidsmæssigt noget større perspektiv, er palæoantropologien. Ud fra evolutionsbiologien som grundvidenskab kan der med nutidens viden gives et væld af udsagn om menneskehedens historie. Ikke kun som biologiske levevæsner, kastet hid og did af miljømæssige betingelser, men netop som kulturvæsner, som en særlig art hvor sondringen mellem biologi og kultur i praksis blev vanskelig allerede for 50.000 år siden, med Cro Magnons kulturelle revolution, og måske principielt vanskelig 
allerede med fremkosten af slægten Homo for 2,5 millioner år siden

Begge bøger tager os på en rejse gennem 6 millioner års historie, fra menneskelinjens udspring hos aberne, via den oprejste gang, de første spor efter kultur, udvandringen fra Afrika, landbrugets indførsel, til civilisationen og byernes fremkomst. Mens Menneskets oprindelse og udvikling er rettet mod de højere læreanstalter (med et teknisk vokabular der krævede en vis omstilling hos denne anmelder), og derfor er mere grundig og bedre til at forholde sig til basale videnskabsteoretiske spørgsmål, så vinder lægmandsudgaven, Da mennesket blev menneske, faktisk hos mig på grund af en imponerende billedside, der er med til at understøtte, hvor fantastisk en indsigt i egen udvikling mennesket er $\mathrm{i}$ besiddelse af.

Med stor dygtighed rammer P.K.A.J. en pæl gennem den mudrede forestilling om, at undren i forhold til menneskets stilling $i$ verden er forbeholdt de humanistiske videnskaber og særligt filosofien. Palæoantropologien, med dens tværfaglige karakter af biologi og arkæologi, maner på en nøgtern måde til refleksion over en række spørgsmål såsom 'Hvad er naturen?', 'Hvad er mennesket?', 'Hvor kommer vi fra?', spørgsmål som kun lader sig behandle under hensyntagen til at menneskets forståelse af sig selv, og dermed af sin egen historie, har været længe undervejs.

Frank Beck Lassen
Krig

Bo Kristian Holm (red.), Krig - dens legitimitet i religion og politike, Anis, Frederiksberg, 2005, 164 sider, kr. 179,-

Der er penge i krig; eller rettere: der er bøger i krig. Mængden af udgivelser, der omhandler krig er hastigt voksende. Det er ikke så underligt, når man tager krigen mod terror $\mathrm{og}$ Danmarks deltagelse heri i Afghanistan og Irak i betragtning. Krig er både et taknemmeligt emne, da det er påvirket af og påvirker så godt som alle områder af menneskelivet, samt et besværligt emne, da behandlingen ofte reduceres til moraliseren eller platituder.

Forlaget Anis og Teologisk Fakultet ved Århus Universitet har startet et glimrende samarbejde omkring udgivelsen af artikler med udgangspunkt i konferencer på Teologi, hvor forholdet mellem religion, etik, politik $\mathrm{mm}$. undersøges. Tidligere er udkommet en bog om menneskerettigheder Tanken om menneskets ret. Denne gang er formålet at undersøge relationen mellem religion og politik, nærmere betegnet hvordan religiøse forestillinger om krig og vold tjener som legitimering af faktisk førte krige. Irak-krigen som kontekst er tydelig i bogens bidrag, men de fleste af artiklerne er på ingen måde bundet til denne kontekst og vil kunne læses med udbytte længe efter den sidste amerikaner er blevet tvunget ud af Irak. Der er dog tale om ofte meget interne indlæg, og bogen når næppe sin ambition, da flere af indlæggene 